Mercator, Fortaleza, v. 17, e17002, 2018.

DOI: https://doi.org/10.4215/rm2018.e17002

ISSN: $1984-2201$

Copyright @ 2002, Universidade Federal do Ceará

\title{
CORPORATE PLANNING AND AIRPORT CONCESSION IN BRAZIL
}

\author{
TEIXEIRA, Sergio Henrique Oliveira ${ }^{\text {a* }}$
}

(a) Msc. in Geography. Elementary school teacher São Paulo. ORCID ID: https://orcid.org/0000-0001-8044-7854. CURRICULUM LATTES: http://lattes.cnpq.br/9004866318178881

Address: UNICAMP, Rua João Pandiá Calógeras, 51, CEP: 13087970, Campinas (SP), Brasil. Tel: (+55 19) 992941116

E-mail: sergiothot@yahoo.com.br

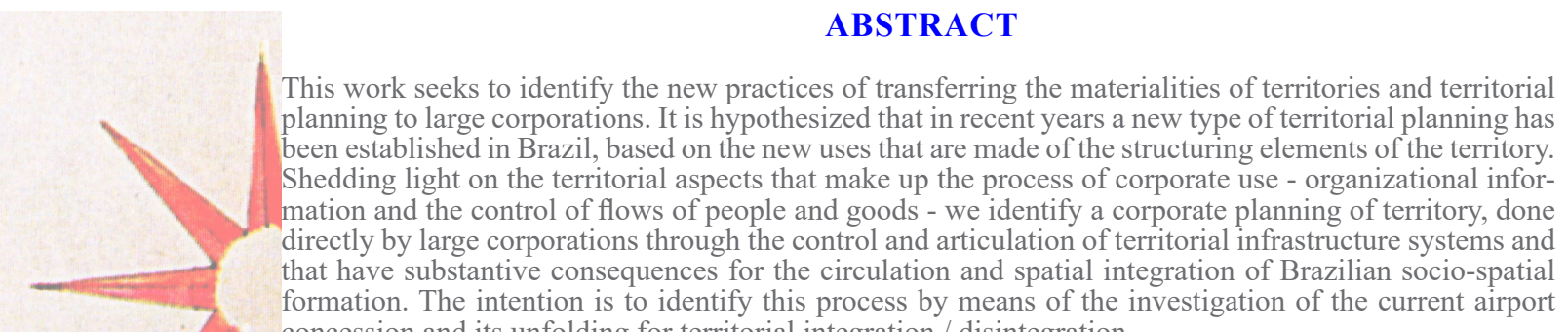
concession and its unfolding for territorial integration / disintegration.

Keywords: Corporate Planning; Corporate Use; Concessions; Territorial dispossession.

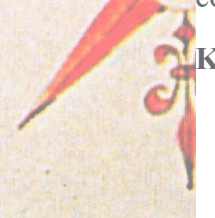

\section{RESUMO / RESUMEN}

\section{PLANEJAMENTO CORPORATIVO E CONCESSÃO AEROPORTUÁRIA NO BRASIL}

Este trabalho busca identificar as novas práticas de transferência das materialidades do território e do planejamento territorial para as grandes corporações. Levanta-se a hipótese de que nos últimos anos se conformou no Brasil um novo tipo de planejamento territorial, pautado nos novos usos que são feitos dos elementos estruturadores do território. Lançando luz sob os aspectos territoriais que compõem o processo de uso corporativo - a informação organizacional e o controle dos fluxos de pessoas e mercadorias - identificamos um planejamento corporativo do território, feito diretamente pelas grandes corporações por meio do controle e articulação dos sistemas de infraestruturas territoriais e que têm decorrências substantivas para a circulação e a integração espacial da formação socioespacial brasileira. Pretendemos identificar esse processo por meio da investigação da atual concessão aeroportuária e seus desdobramentos para a integração/desintegração territorial.

Palavras-chave: Planejamento Corporativo; Uso Corporativo; Concessões; Espoliação Territorial.

\section{PLANIFICACIÓN CORPORATIVA Y CONCESIÓN AEROPORTUARIA EN BRASIL}

Este trabajo busca identificar nuevas formas de transferencia de las materialidades del territorio y la planificación territorial para las grandes corporaciones. Plantea la hipótesis de que en los últimos años se estableció en Brasil un nuevo tipo de planificación territorial, con base a los nuevos usos que se hacen de los elementos estructurales del território. Arrojando luz sobre los aspectos territoriales que conforman el proceso de uso corporativo - información y control de la organización de los flujos de personas y bienes - es identificado un territorio de planificación corporativa, hecho directamente por las grandes corporaciones a través del control y la coordenacíon de los sistemas de infraestructuras territorial y tienen derivaciones substantivas para em movimiento y la integración espacial de la formación socioespacial brasileña. Tenemos la intención de identificar a este proceso mediante la investigación de la actual concesión del aeropuertos e sus consecuencias para la integración/desintegración territorial.

Palabras clave: Planificacion Corporativa; Uso Corporativo; Consesiones; Expoliación Territorial. 


\section{INTRODUCTION}

The importance of transportation systems in territories for territorial development and planning (analyzed as transport, mobility, fluidity, flows or even as spatial interactions) is consecrated in the most diverse analyses of Geography, Regional Economy and regional development specialists. The choice of air transportation systems to investigate the corporate planning of territory was therefore justified by the hypothesis that this system of transportation has taken on an increasingly important role in recent processes of territorial articulation in the face of the emergence of a corporate planning of the territory.

This becomes progressively important in view of the need for an increasingly rapid and necessary fluidity to the pattern of flexible / just in time accumulation (HARVEY, [1989] 2014, ANTUNES, 1999, BENKO, 1996), ${ }^{1}$ which made the air transportation system one of the main articulators of the movement of people and high value-added goods in the process of carrying out the circulation of globalized capital. On the other hand, the magnitude and importance of this system, from its construction, maintenance and expansion, whether of airports and their connections, justify its importance in territorial planning, since it was under State administration - on the various scales of the federation - that a dense network of airports and air transportation connections was established, supporting the period of state investment in public systems in the 1950s / 60s / 70s in Brazilian socio-spatial formation (SANTOS, 2005). ${ }^{2}$

In this sense, the content addressed in this paper seeks to elucidate some points to be investigated regarding the characteristics of territorial integration and disintegration arising from the concession process and its importance for territorial planning on its various scales. The analysis of the structure of the air transportation system, conceived as a regional integration infrastructure, can reveal the even more perverse characteristics of its spoliation (HARVEY, 2004) through corporate use of the territory (SANTOS, SILVEIRA, 2001).

\section{THE AIR TRANSPORTATION SYSTEM AND TERRITORIAL INTEGRATION}

Territorial management, intoned by global consulting firms and large corporations as (corporate) planning - under the euphemism of strategic planning - deepened regional asymmetries and inequalities, fruit of the territorial division of Brazilian socio-spatial formation, leading to greater regional specialization with an emphasis on the role of the polarizing cities of the Brazilian urban network, which today take on regional and national commanding roles. The air transportation system accompanies the design of the network of cities and also shapes its historical characteristics of centrality, polarization, integration and disintegration. ${ }^{3}$

Air traffic data on the air transportation system, provided by the Department of Civil Aviation (DAC) each year, with details on each airport managed by INFRAERO, make it possible to organize flow maps of the whole territory and intercross these with the network of cities. These databases help

(1) Flexible accumulation / Just in time was the mode of production that replaced the Fordist mode of production. Characterized as flexible, this mode of production organizes the pro-cesses of production, circulation and consumption in a Toyotist manner, making labor rela-tions more flexible and fragmenting space in productive circuits on a global scale.

(2) Historically, economic and social patterns have been delineated in such a way as to determine how technical objects are available in a particular nation. Lenin (1982) identified this process called Economic and Social Formation, and Santos (1977) identified this economic and social formation adding its spatial constraints, thus coining the concept of Socio-spatial Formation. Therefore, what should be understood as socio-spatial formation is the economic, social and spatial difference between different nations within an unequally and agreed form of organized capitalism. Here, the concept gains a crucial force for geographic analysis. It is, as Corrêa (2000, p 123) explains, "a theoretical effort to make explicit the specificities with which a given mode of production concretely manifests itself. Defined by means of principal, invariant characteristics, a given mode of production materializes in various socioeconomic formations".

(3) This work adopts territorial disintegration as a hypothesis of the ongoing process in Brazilian socio-spatial formation. 
to reveal the importance of fixed airports for the organization of territorial planning, the main flows anchored in the analysis of the urban network, and also reveal the importance of the transportation system for the analysis of the city network, making it possible to compare the historical series and airport interconnection capacities and assess trends.

An initial analysis of the 2010 data reveals a structure of interconnections that follows the centralized and polarized structure of the network of Brazilian cities. At the same time, they reveal a great capillarity in local, regional and inter-regional exchanges. The network's characteristics show a high connectivity between the cities that make up the main hubs ${ }^{4}$ in the national territory. The city of São Paulo - SP stands out as the main centrality of the network of air flows in the Brazilian territory, establishing direct and indirect connections with practically all the cities of the air transportation network. Of the total of 878 main connections carrying 72 million passengers, the city has 67 connections ( $7.6 \%$ of connections), however, a small number of connections carry a total of 32 million passengers, or $44.9 \%$ of the entire network. This is because the city is the country's great national metropolis, which, according to Santos (1990), IBGE (2008) and Corrêa (1992), accumulates functions at the highest levels of the network. São Paulo - SP, accumulates the functions of a business management center and also has a high level of centralization of public management (IBGE, 2014). Its predominance in the transportation of passengers is also related to the concentration of sophisticated services, the headquarters of large companies and advanced industry, as well as dividing the financial center of the country with the city of Rio de Janeiro - RJ (IBGE,2008). Also significant is the fact that the city has two airports (Guarulhos and Congonhas) that meet the demand from more than 20 million people who live in the metropolitan region of São Paulo, the largest metropolis in the country.

Brasília - DF, has a total of 49 connections (5.5\% of the network) that carry just over 9 million passengers, $13.2 \%$ of the total network. The city stands out for its central position in the territory that makes it the second main interconnection hub of the north and center-west regions. In addition, passenger demand is intense because as the country's capital, the city occupies the primary position of public management in the territory.

The rest of the network transports about 30 million passengers in its 763 main connections. That is, the cities of Brasília and São Paulo have flows that overtake all the rest of the network (Table 1 and Table 2).

Table 1 - Air Connections and Passenger Flow (Brasília - DF and São Paulo-SP) - 2015

\begin{tabular}{ccccc}
\hline City & Connections & $(\%)$ Links & Passengers & (\%) Passengers \\
SÃO PAULO - SP & 67 & 7.6 & $32,206,704$ & 44.9 \\
BRASÍLIA - DF & 49 & 5.5 & $9,433,986$ & 13.2 \\
THE REST OF THE NET- & 763 & 86.8 & $30,110,296$ & 41.9 \\
WORK & 879 & 100 & $71,750,986$ & 100 \\
TOTAL &
\end{tabular}

Source: IBGE (2010) and ANAC (2015). Produced by: Sérgio Teixeira

Table 2 - Regional Passenger Connections and Flows in Brazil - 2015

\begin{tabular}{ccccc}
\hline Region & Connections & (\%) Connections & Passengers & (\%) Passengers \\
North & 179 & 20.36 & $2,328,305$ & 3.24 \\
Northeast & 160 & 18.2 & $7,608,095$ & 10,60 \\
Midwest & 122 & 13.88 & $10,813,966$ & 15.07 \\
South & 133 & 15.13 & $3,428,626$ & 4.78 \\
Southeast & 285 & 32.42 & $47,571,994$ & 66.31 \\
Total & 879 & 100 & 71750986 & 100 \\
\hline
\end{tabular}

(4) Hubs are airports with larger amounts of flows. 
Regarding the regional issue, figure 1 indicates the continuity of the concentration patterns in the southeast region and in the concentrated region. The southeast region has $1 / 3$ of all connections in the network of flows and transports $66.3 \%$ of all passengers of the main lines of flows. The central-west region confirms its recent dynamism associated with the expansion of the agricultural frontier and with the public administration center installed in Brasília - DF, transporting 15.07\% of all passengers in the network. The city's Juscelino Kubistchek international airport is the node of the Center-west region, becoming the North's territorial interconnection hub with the Southeast region. The Northern and Northeastern regions appear as the rarefied regions of the territory, because although they concentrate almost $40 \%$ of the connections, they only carry $14 \%$ of the passengers. The complex formed by the concentrated region has a dense, highly fluid interconnection, offering a greater interconnection capacity in the territory (figure 2).

\section{CENTRALITY OF FIXED AIRPORT SYSTEMS}

The analysis of the evolution of the flows of Brazil's 20 main airports reflects the political, economic and spatial centralization of the technical systems. They also follow and reinforce the network of city hierarchy and according to the IBGE (2008), only Campinas - SP occupies a higher hierarchical role in the network of air traffic flows than its place in the network of cities. The city of São Paulo - SP, with its two airports (Guarulhos and Congonhas), appears as the main flow of the network. Brasília - DF appears next, just ahead of Rio de Janeiro.

Figure 1 shows that the structure of the airport network follows the evolution of the network of cities associated with the centrality of the concentrated region. The network's organization follows the pattern of the division of labor, not just regional imbalances. It is the organization of the territorial division of labor in the socio-spatial formation that determines the concentration patterns.

São Paulo - SP, is central in the flow of passengers because of its function as a business management center within the network of cities. Brasília - DF appears with the air interconnection network for being the administrative management center (IBGE, 2008, IBGE, 2014, Corrêa, 1977). An analysis of the sector's evolution shows that today the pattern of the territorial division is the result of a historical process that endowed the Southeast with the greatest inputs of technical infrastructures, forming, together with the South and Central-West regions, the concentrated region of the territory. ${ }^{5}$ Brasília - DF has taken on a prominent role in the network, since its central position in the country organizes flows with other directly polarized metropolises like Manaus - AM, Belém PA, Fortaleza - CE, Recife - PE and Salvador - BA. We can say that Brasilia has taken on the role of a territorial "bridge" with the North and Northeast regions within the concentrated region. It is worth highlighting that the regional capitals of Campinas - SP, Florianópolis - SC, Natal - RN and Vitória - ES, are important because they have flows ranging from 1 million to 5 million passengers; flows compatible with the metropolises polarizing the network.

Figure 1 demonstrates the evolution of the connections of the air transportation system in its passenger flows from 1970 to 2010. In this map, it is clear that the system's density is the most relevant in the concentrated region of Brazil. The city of São Paulo has confirmed its centrality and omnipresence in the territory (SANTOS, 1990) since the 1970s. Rio de Janeiro - RJ continues to have the primacy of links with São Paulo - SP, but the role of Brasília - DF and some of the metropolises of the Northeast are noteworthy. It is noted that in 1972 the Southeast region had already reached flows with more than 3 million passengers. In 1980, the transportation system expanded

(5) This denomination - Concentrated Region - was introduced in the geographic literature with the surveys directed by Milton Santos and Ana Clara Torres Ribeiro in 1979. This region is made up of the states of Rio de Janeiro, Espírito Santo, Minas Gerais, São Paulo, Paraná, Santa Catarina, Rio Grande do Sul and parts of the Midwest. Its genesis is due to the consolidation of the technical base present in these regions, mainly coming from the coffee economy and State investment in infrastructure for companies, especially in the region surrounding São Paulo, and the increase of technical informational objects. Demographic density, in turn, also drives the division of labor and the specialization of these areas, which increasingly concentrate material and immaterial increases in globalized production. 

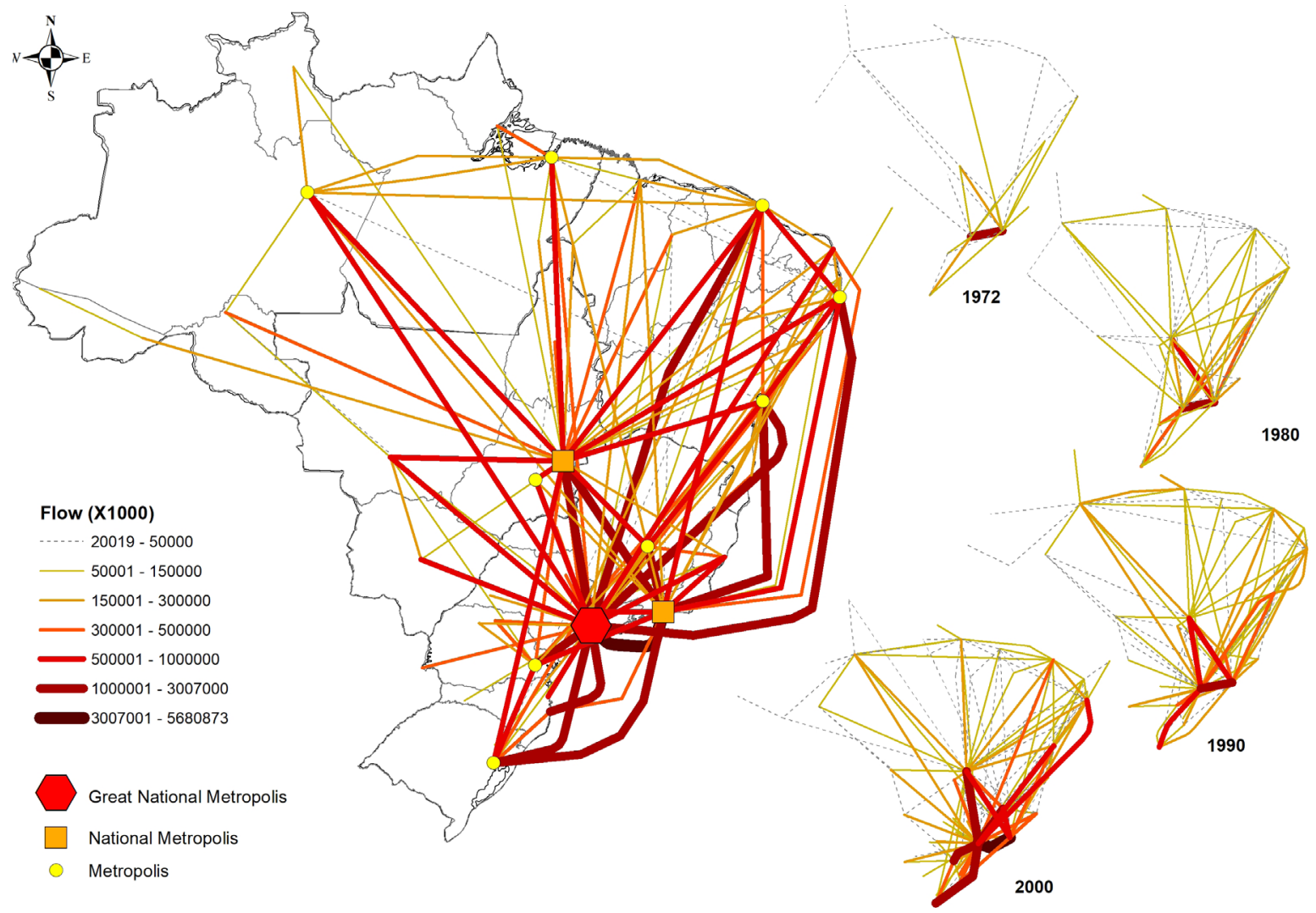

Source: Yearbook of air transportation 1950. Brasilia - DF. National Agency of Civil Aviation - ANAC [1951]. Until 1974 published under the title Anuário Estatistico da Aviação Civil. Until 2004 , published by the Department of Civil Aviation - DAC, Rio de Janeiro.
Available at <http $>$ www. anac gov. briestatistica/estatisticas1. asp Accessed in April 2013

Cartographic design

Figure 1 - Passenger Flow - The Evolution of the Family of Territorial Forms (1972-2010)
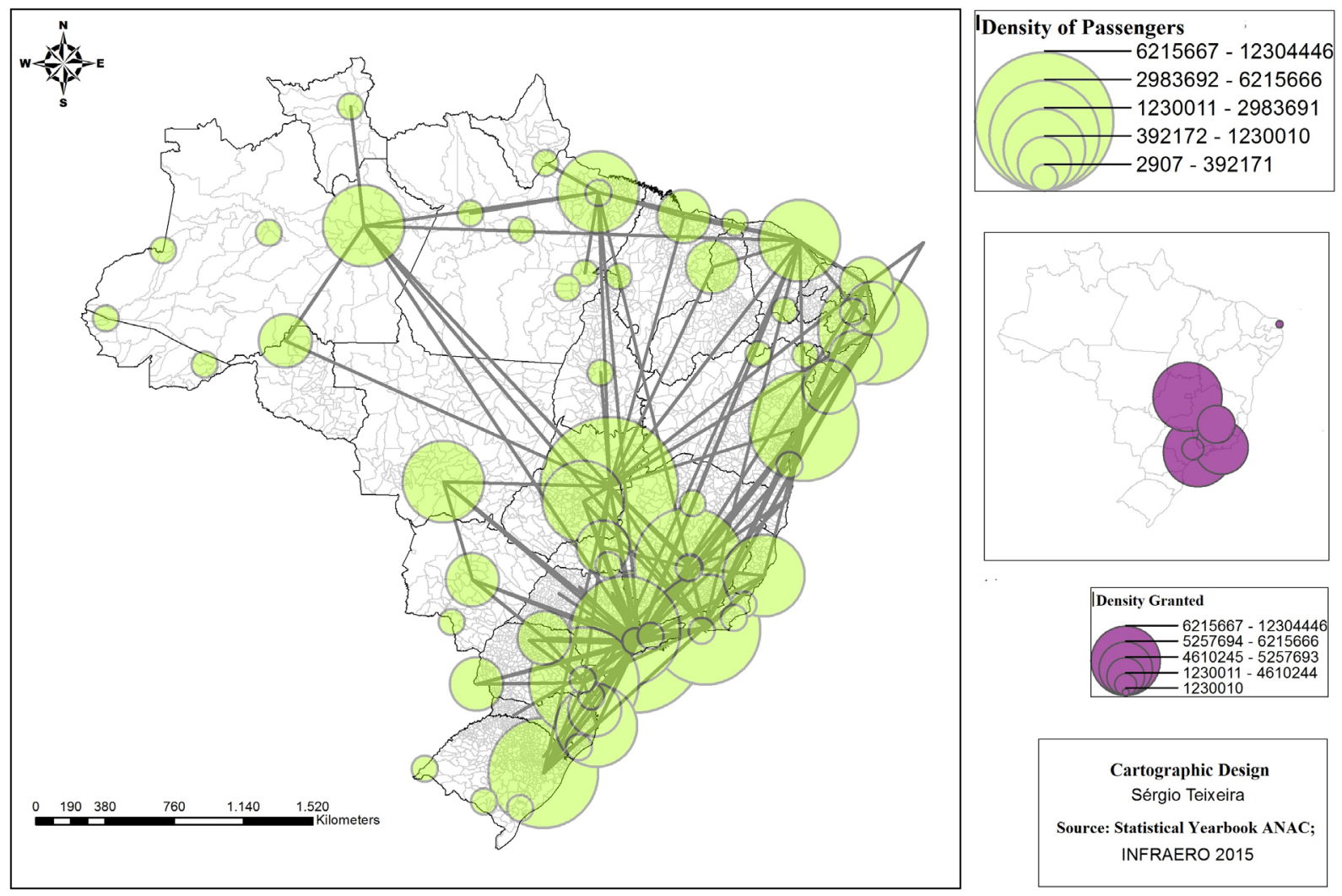

Figure 2 - Densiy of Passenger Boarded by Infraero and Granted Airports (2015) 
considerably and had already established connections of more than 50 thousand passengers with the north and northeast, highlighting the Manaus - AM / Belém - PA connection that, in 1990, began to form distribution bases of people in the North region. In the 2000s, the highlights were the high density connections established in the concentrated center-west and south regions and their highly connected links in all regions in 2010.

These data confirm that Brazilian socio-spatial formation is marked by the dynamics of the networks that have formed in a vast territory, of heterogeneous integration, distributed in points of densities and rarefaction (SANTOS, 2008). These characteristics are major challenges for territorial planning, ${ }^{6}$ given that territorial heterogeneity is an obstacle to the formation of an integrated national market, necessary for development (BRANDÃO, 2007). Currently, economic, social and technical regional disparities are the greatest difficulty for comprehensive planning seeking territorial integration.

This dynamic was an endeavor to overcome difficulties, from the 1960s, with the construction of the theory of underdevelopment, ${ }^{7}$ which formulated an integration from the formation of technical networks in the territory, be they of people (mainly road transport) and of goods, but also - in a complementary and increasingly intense manner - of energy and information. This process was even more intense due to the increasingly rapid dynamics demanded by flexible accumulation that has placed rapid transport such as air travel and the networks of communication and organization of the telematics networks at the forefront of the accumulation process.

The planning associated with the necessary integration of the territory was formed in the Juscelino Kubitschek and João Goulart governments (1956 - 1964), however it was deepened in the years of the military governments (1964 - 1988). In this way, there was an attempt to integrate the flow of the technical base located in the core of the country, scattered from the coastal axis of the concentrated region. The process of import substitution planning only deepened this trend, which further differentiated the more consuming and more productive regions by their extraverted integration into the global market. The technification of the territory (SANTOS, [1988] 2008; SANTOS; SILVEIRA, 2001) allowed the circulation (of transport and information) to happen throughout the territory, but in a fragmented way, giving places and regions densities and rarefaction in a real geography of networks (SANTOS, 1999).

Therefore, the connection of the flows became fundamental for the organization of companies in a period of necessary attraction of productive infrastructures to the territory. However, some infrastructure impasses had to be transposed, since the railway network became obsolete for the companies' new speed in the production, circulation and use of the territory. Thus, investments in road and air transportation systems passed the frontier zone of the expansion of capitalist circulation in the Brazilian socio-spatial formation. New productive arrangements also expanded the systems of electric power flows; fixed and flows of various orders were extended in the territory, but there was still a concentrated and unequal pattern between the regions.

(6) By territorial planning we understand the conflicting practice of ordering politics, economy and territory having in view a future project related to the construction of the nation. From this point of view, we do not propose to understand territorial planning as a model, and we propose, in agreement with Oliveira (1987) and Santos (2007), to understand territorial planning as the spatialized manifestation of conflicts within the arenas of disputes between social classes, corporations and the state.

(7) The effort in the national debate and the synthesis of national projects that could overcome underdevelopment was undertaken by numerous Latin American and Brazilian intellectuals. The latter are notable, and among them, the work of Furtado ([1959] 1982), Prado Jr (1966) and Fernandes ([1975] 2006) seem to us representative of this effort. Starting from methodological matrices and categories of distinct analysis, these authors, each in their own time, sought to guide an explanation of national problems by relating the changes of world capitalism to the role played by the underdeveloped countries in the international division of labor and, among them, we can say that they had the common goal of overcoming the conditions of underdevelopment and dependence. 


\section{LOGIC OF CONTROL OF INFORMATION BY NEW CORPORATE AGENTS}

The use of territory (SANTOS; SILVEIRA, 2001) occurs through the control of the techniques and actions that operate on its materiality. The ascendancy of information and technique as new engines of the period constituted a new geographical environment that develop through the enormous amounts of information that qualify its uses: a technical-scientific-informational environment (SANTOS, 1999). We are facing a world in which the unequal distribution of information is becoming ever more decisive, both for capital and for social struggles; new forms of mobilization explode in society, in which the uses of information, as for example through social networks, have served the social opposition movements in their daily struggles and conflicts. In information the era of globalization reveals its contradictory character of possibility, banality and organicity (SANTOS, 2001).

It is therefore important to ask who controls the information, who disseminates it, its uses and role in the restructuring of the economy and space. Information interconnection networks have been constantly debated in territorial planning documents, however, there are few analyzes that can set aside common sense and clarify what the information and its status would be. Before investigating the issue, it is necessary to differentiate the information analyzed herein. According to Mattelart (1994), it is not about banal information, that all potentially have unlimited access to. We focus on organizational information, which few companies and few States access, precisely because it is strategic for the accumulation, power and control of the use of territory. Therefore, for the organization of capital, it is necessary to control information as a way of organizing power in the territory. For Santos (1999, p.147)

Centralized control and hierarchical organization lead to the installation of inegalitarian structures, since the essential information is exclusive and only transits in restricted circuits. About ninety percent of all satellite-delivered data is between large corporations and half of transnational messages fit within multinational corporate networks.

There is no denying the increasingly present role of information since the 1970s, as Benko (1996) pointed out. It was in search of an added value increasingly thirsty for agility that the last quarter of the twentieth century capitalism was marked by a broad restructuring of production based on information systems. Large global and strategic consulting firms arranged production activities by reorganizing large private companies and state-owned structures. ${ }^{8}$

The initiative to move the control of transportation infrastructures to large corporations was not new. From the beginning of the 1990s, with the advent of neoliberalism, there had already been the intention to move this process forward. However, the operationalization of the spoliation of transportation infrastructures was not successful, since the energy and communication infrastructures were prioritized. Only from the 2000s would the transfer of transportation infrastructure such as railways, highways, ports and airports become operational. Thus, these systems moved to the front line of the spoliation process. Preparations for the transfer of the air transportation system began with the process of publicizing INFRAERO as an inefficient company in the face of the increasing demand necessary for economic growth and the improvement of the average income of the population. With

(8) These are consulting firms that became known as the "big four" by controlling the consulting and auditing market around the world: Pwc, Delloite, E \& Y and KPMG. Besides these companies there are companies known as strategy consultancies. These deal with the highest level of interactions in privately held companies that enter into large mergers linked to the financial markets, with Mckinsey \& Company, Bain and DBO as the leading companies. 
this, starting in 2003, the new government (Lula I, 2003-2006) began to request consulting firms and state entities linked to the armed forces ${ }^{9}$ for studies on the concession (See Chart 1).

Chart 1 - Studies on the Privatization of Airports in Brazil

\begin{tabular}{|c|c|c|}
\hline Year & Study & Goal \\
\hline 2003 & $\begin{array}{c}\text { Airports and Privatizations: airport priva- } \\
\text { tization proposal for Brazil (AIR FORCE } \\
\text { COMMAND). }\end{array}$ & $\begin{array}{c}\text { Inform about the development of the airport privatization process and } \\
\text { suggest concession options that may fit the model of airport administration } \\
\text { adopted in Brazil }\end{array}$ \\
\hline 2008 & $\begin{array}{c}\text { 2008 Regulatory Performance Report } \\
\text { (ANAC) }\end{array}$ & $\begin{array}{c}\text { Draw up measures to remove non-operational restrictions at central air- } \\
\text { ports; the creation of an entry rule at airports with limited new flights; the } \\
\text { release of international tariffs; and the preparation of a regulatory frame- } \\
\text { work for the concession of Brazilian airports to private initiative }\end{array}$ \\
\hline 2008 & $\begin{array}{c}\text { Air Transportation Sector and Airports } \\
\text { Concession Projects (BNDES) }\end{array}$ & $\begin{array}{c}\text { The study sought to legitimize future BNDES interventions in the process } \\
\text { of privatizations operated as concessions }\end{array}$ \\
\hline 2011 & $\begin{array}{c}\text { Economic study of the regulation and com- } \\
\text { petition of the airports sector (ANAC) }\end{array}$ & $\begin{array}{c}\text { It traced a complete review of privatization and for the first time adopted } \\
\text { the concept of concession as the best model for Brazil }\end{array}$ \\
\hline $\begin{array}{c}\text { Consolidated Report of the Study of the Air } \\
\text { Transportation Sector of Brazil (MCKINSEY } \\
\text { \& COMPANY) }\end{array}$ & $\begin{array}{c}\text { Carried out a technical evaluation for the development and modernization } \\
\text { of Brazilian Civil Aviation, serving as a political and institutional basis for } \\
\text { the concession process of the main airports in Brazil. }\end{array}$ \\
\hline
\end{tabular}

In 2003, a study was commissioned by the Air Force command that could organize the regulatory apparatus for the privatization of the airports. In the same year, the study "Airports and Privatizations: a proposal for airport privatization for Brazil" was published. The study clearly aimed to "provide information on the development of the airport privatization process and suggest concession options that might be appropriate for the model of airport management adopted in Brazil" (COMANDO DAAERONAUTICA, 2003 p.4). This document was fundamental because, according to our research, it would guide the steps that the government would take to start the concessions. In 2005, the National Civil Aviation Agency (ANAC) was created through Law $\mathrm{n}^{\mathrm{o}} 11.182 .{ }^{10}$ The new Agency replaced the Civil Aviation Department (DAC) ${ }^{11}$ as the civil aviation authority and took on the role of regulator of air transportation in the country. Its responsibilities were to regulate and supervise civil aviation, air transportation and airport infrastructure activities. Such agencies, as shown by Antas Jr. (2005), play the role of legitimizing privatizations by the State in a supposed inspection process that gradually molds companies in a hybrid regulation of processes. In the same sense, ANAC has fulfilled the role of organizing the normative structure for the concession of the sector following the aforementioned directives. In 2008, ANAC published the document "Regulatory Performance Report 2008". In this first document, ANAC pointed out the general lines of the concession process, which first criticized the sector as inefficient and suggested concession as a way out for the system to function well:

This year was marked by ANAC's effort - integrated with all bodies of the Brazilian Civil Aviation System - to normalize regular aviation operations, after the critical moments of 2006 and 2007, while creating new paradigms that allowed society and social agents to regain confidence in aviation as a fundamental element for economic development and national integration" $(. .$.$) "In this sense, ANAC has$ developed a series of initiatives: the development of measures to remove non-operational restrictions

(9) The relationship between the sector and the armed forces in the concession process still needs to be better investigated, given that airports were key parts of the military sector before the concession. The main air traffic management network recruitment passes through schools and courses offered by the Air Force.

(10) The complex of transformations triggered by the creation of the National Privatization Plan (PND) when applied to the different sectors, implied the creation of more norms oriented to govern the relationships between the corporations and of these with the territory. For Antas Jr. (2005, p. 193) it is "in this universe of changing roles and the emergence of new agents that regulatory agencies began to be created." The creation of several national regulatory agencies presented themselves as holders of the new corporate rationality in the territory by organizing the processes of privatizations and concessions.

(11) The DAC was an integral part of the administrative structure of the Ministry of Aeronautics until 1999. 
at central airports; the creation of an entry rule at airports with limited new flights; the release of international tariffs; and the preparation of a regulatory framework for the concession of Brazilian airports to private initiative" (ANAC, 2008 p.35).

In 2008, the study "Projects of the Air transportation sector and Airport Concession"; was carried out the BNDES team, this study sought to legitimize future interventions by the bank in the airport concession process. In 2009, CONAC - the Civil Aviation Council was created; an advisory body for the president responsible for proposing a national civil aviation policy. This council had the role of forwarding the concession proposals to the presidency. In the same year, through the Project BRA / 01/801 - ICAO - ANAC, the "Economic Study on the regulation and competition of the airport sector" was commissioned by ANAC. The study, which was denser than the previous ones, organized a complete review of privatization and for the first time adopted the concept of concession as the best model for Brazil. A chart showing studies that indicate the process of transferring the sector to the corporations follows below.

It is noteworthy that all these studies were practically ignored in the final process, in which the Mckinsey \& Company Study exceeded. In our view, this was due to the need to legitimize the concession internationally, since the aforementioned body did not have the same knowhow as large consulting firms. Moreover, what is noticeable in all the reports is the incentive to spoliate the system in the face of a possible bottleneck, legitimized on the grounds of holding major events and growing demand.

\section{CORPORATE SPOLIATION AND THE AIR TRANSPORTATION SYSTEM}

The model used for the concessions was an enhancement of the spoliation processes of the previous period. To get the apparatus moving, some experiments were done with the concession of the São Gonçalo do Amarante Airport- RN.

The first experiment was to designate a concession model. The model designated a series of corporate assumptions, including the responsibility for operations and the transfer to the State after the concession period, in the case of São Gonçalo Airport a 38-year concession. Another experiment with the airport was the composition of the Inframérica airport operator, made up of the association of the Brazilian group Engevix and the Argentine group Corporación América. After its first experience in São Gonçalo, this operator won the International Airport of Brasília for R \$ 4.5 billion. Using the normative model, another two rounds of concessions were made with the addition that $49 \%$ of the shares of the airports granted should be held by INFRAERO. It appears that state participation took place in a way that ensured that the consortia would not be solely responsible for the investment, but the State would also take on much of the adaptation of the infrastructure.

In the first round of concessions, the airports of Guarulhos - SP, Brasília - DF and Campinas - SP were sold for the amounts of R\$ 16.21 billion, R\$ 4.51 billion and R\$ 3.82 billion, respectively. Counting on immediate investments, INFRAERO took on the investments of R 1.48 billion in Guarulhos - SP, R\$ 180 million in Brasília - DF and a surprising R \$ 6.46 billion in Campinas - SP. The second round of concessions maintained the same pattern at Belo Horizonte Airport, in which the auction of the airport was R $\$ 1.8$ billion and INFRAERO's investment R \$ 3.31 billion. It is noteworthy that the announcement of the Rio de Janeiro Airport concession was a change to the extent that the declared amount of investment was less than the auction value, as there were no immediate specifications for investments. For this airport, the figures were R $\$ 19$ billion for auction and R\$ 12.43 billion for investment. ${ }^{12}$

(12) The complete inventory of the concessions and the source of the data are summarized in chart 2 of this publication. 
TEIXEIRA, S. H. O.

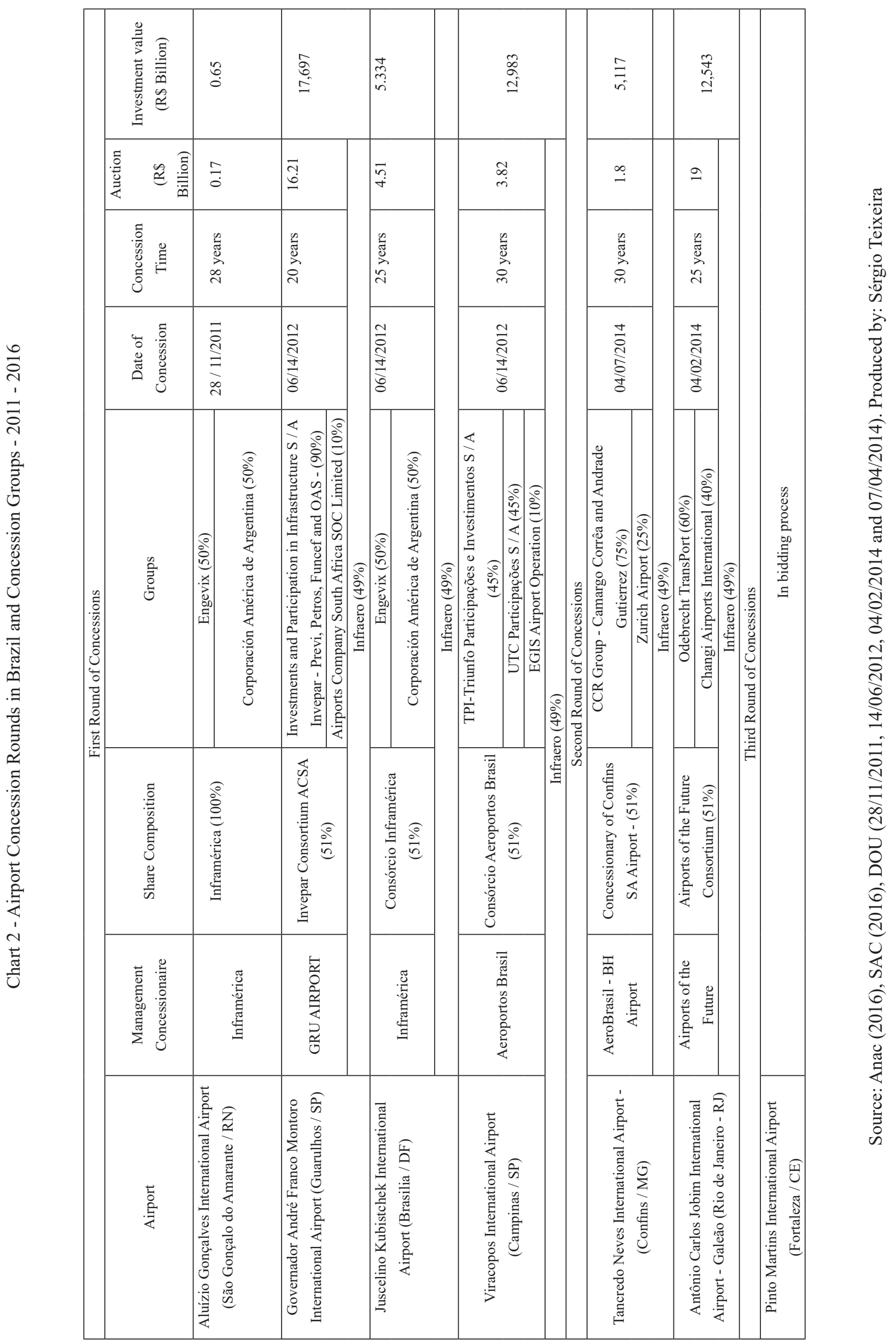


The final result of the concessions, according to the data published in the edict systematized in Chart 2, added up to R $\$ 45$ billion raised by the State. However, it should be taken into account that a good part of this investment was assured in the bidding documents financed by the National Bank for Economic and Social Development (BNDES). ${ }^{13}$

These numbers draw attention, first because the investments were projected from an increase in the flow that might not take place. However, this was one of the criteria to decide on the group that would win the concession of the airports in question. Secondly, contradictorily, the amount paid for the concession also depended on the income destined for the flows of passengers and might not be paid if that flow was not confirmed. This was what was foreseen in the edicts of the concessions, since the amounts described herein were paid in installments, at low interest rates financed by the BNDES, depending on the demand for profits generated at the airports: "The value of the Concession will be paid in annual installments, as of the date and effectiveness of the concession contract until the advent of its term "(ANAC, 2011, p. 27).

Another synonym of corporate logic applied to the territory is the participation of foreign companies in the airport concessions. Under the terms of the concession edict, participants in the auction were Brazilian or foreign legal entities, private pension entities and investment funds, alone or in a Consortium. The announcement, therefore, practically obliged the consortia taking part in the bid to have a foreign partner. That is because, according to the edict, at least one of the partners must have experience in airport management with a movement of more than five million passengers a year, which would not qualify any Brazilian company. It is interesting to note that only INFRAERO has the number of operations and requirements to manage the airports, in which case the concession issue is contradictory. ${ }^{14}$

The role played by the National Bank for Economic and Social Development (BNDES) in this process is noteworthy, as this bank reveals the logic of the Brazilian State towards the state-owned enterprises of the country. In the history of the Brazilian privatization process, the BNDES released funds for companies to finance the privatization of public utilities, fulfilling the role of catalyst for extraverted actions, since in many cases foreign companies were involved. In short, it was a question of taking on the risks of non-payment at the expense of the labor funds that make up the bank's reserves. ${ }^{15}$

The consequence of this process for regional interconnection may soon have damaging effects on the airport network, since the system works with crossed subsidies: profitable airports support those operating at a loss. Spoliated airports account for $88 \%$ of INFRAERO's profitability. As a way to neutralize this possible disruption, the National Civil Aviation Fund (FNAC) was created to collect between $5 \%$ and $10 \%$ of the profits of the consortia in grants. However, the edict does not specify the collection in the case of loss.

A final relationship of the content discussed in the research deserves to be highlighted in an introductory way. The control of this system is fundamental for the strategies of territorial planning, as much for the aspect of circulatory control as for the potential of regional interconnection. In Brazil, it is one of the largest engineering systems in public ownership, with a large network dispersed in the territory and with the main airports centralized and operated by the State, via INFRAERO. It should be noted that, even though the transportation service is carried out exclusively by private companies, they are subject to state regulation and supervision by the National Civil Aviation Agency (ANAC) and the Air Space Control Department (DECEA). Its growing strategic position in view

(13) “Of every R $\$ 100$ invested, R \$ 70 would come from the BNDES and other sources of financing and R $\$ 30$ from the partners. Of the R\$ 30.0, R\$ 14.7 would still come from Infraero (...) "(Secretary of civil aviation of the President of the Republic. Valor Econômico, 10/20/2011)

(14) It is important to highlight that we do not propose to analyze the conformation of the groups that started to manage the airports granted in this work. However, the analysis in chart 2 shows that the fields of the concessionary companies are very diverse. These include airport management companies, food corporations and public and private pension funds.

(15) BNDES resource funds: FAT - Worker Support Fund; FGE - Fund of Export Guarantee; PIS- Social Integration Program; PASEP - Civil Servant Patrimony Program. 
of the new territorial configuration of the production organization placed the airport network at the center of the plundering processes of the territory unleashed from the 1990s.

Opposing the role of the 1970s, in the 1990s the state was responsible for privatizing the same apparatus it had consolidated in its control in the preceding decades. In this process, several state-owned enterprises passed to private administration by large corporations through privatizations, such as the electric energy system, mining, and so on. However, because of their high investment costs transportation systems did not enter into the corporate strategies of that time. Likewise, they were prepared for this future process - supporting the observations of Harvey (2004, [1982] 2013) and Moraes (2000) on the plundering of territorial funds on the permanent platform of spoliation that the national territory has become (BRANDÃO, 2007). Maintaining the pattern of underdevelopment with territorial reserves of state infrastructure, Brazilian socio-spatial formation would become a privileged locus for the spatial adjustment strategies of big capital. This process would take on even more modern features through new regulatory and normative forms that have been elaborated and reorganized since the 2000s with public-private partnerships and concessions.

The survey done for this study shows that the airport concessions extend though the whole territory. It can be observed in map 2 that of the 879 pairs of origin-destination connections of the transportation system's network of flows, which carry a total of 72 million passengers, 67 pairs of connections refer to São Paulo - SP transporting 32 million passengers; 56 pairs of connections referring to Rio de Janeiro-RJ carrying 11 million passengers; 52 pairs of connections referring to Belo Horizonte - MG that carry 2.5 million passengers; 50 pairs of connections referring to Brasília - DF that carry 9.4 million passengers; 26 pairs of connections referring to Campinas - SP that carry 1.2 million passengers and 14 pairs of connections referring to Natal - RN that carry 60 thousand passengers. Therefore, there are about 57 million passengers originating from granted airports, that is, about $80 \%$ of the passengers transported.

The analysis of air connections in figure 2 also indicates the number of interconnection lines that are now spoliated in the concessions, demonstrating that the extensions of the spoliated flows cover the whole network starting from the main centers of the concentrated region of the territory.

The analysis of the density of passengers boarding at the airports demonstrates a network that has been spoliated through the capacity of the fixed. The southeastern region has the highest boarding rates at its main airports, which boarded more than 60 million passengers in 2015 . The purple on map 2 highlights the densities of the airports spoliated by the concession process. It can be observed that the largest airports have been spoliated and are currently under the control of large consortia formed by gigantic corporate agents such as financial funds and national and international corporations. ${ }^{16}$

The investments required from the corporations in the conceded airports tend to open up more possibilities of flows that are occupied by the airlines already operating in these localities. In this way, companies abandon those flows that are outside the denser network, causing network flows to grow in the short term. In the medium term, the consequence was the axing of lines with lower capacity, located in the airports that were not concessions; this can be aggravated if there is no payment of the grants ${ }^{17}$ which are the possibility of investment in airports with lower flows. Thus, territorial disintegration was promoted further in favor of a regional re-concentration of flows, which, as we have seen in the operation hosted by INFRAERO, has been increasing.

(16) The airport of Guarulhos / SP is an exemplary case. The largest airport in the country was sold to the Invepar consortium, which includes the Banco do Brasil pension fund (PREVI), Petrobras pension fund (PETROS), Nossa Caixa pension fund (FUNCEF), the contractor OAS Engineering and the international company Airports Company South Africa SOC Limited - which privately operates nine international airports, among them the ultra-modern airport of Mumbai.

(17) The grants are annual benefits that companies are obliged to pass on to the government for the privatization contracts. The hypothesis raised became a concrete fact with the publication of Provisional Measure 779/2017, which allows the concessionaires of airports to request the reprogramming of the payment of the grants. 
What we have seen so far regarding corporate planning with its inherent process of spoliation seems to confirm Cano's (1997) thesis of a spatial re-concentration in the southeast region and, we add, throughout the concentrated region.

maintaining neoliberalism and introducing significant doses of "modernization" (new processes or more complex sectors with more sophisticated technology) there will be a spatial productive reconcentration (in SP and adjacent areas), to the detriment of the national periphery, since that modernity, as is well known, cannot be located in any type of economic space, but only in those that have special conditions to receive more modernity (CANO, 1997 p. 104).

\section{FINAL CONSIDERATIONS}

The intense spoliation to which the national state and Brazilian cities are subjected has paralyzed any attempt at planning that does not operate according to the designs of large corporations. It is now only about corporate planning. This policy of neoliberal adjustment of openness to large corporations, privatizations and concessions, further exacerbates the regional and social disparities of Brazilian socio-spatial formation. Thus, with the opening up to companies, organizational restructuring and the insane search to overcome territorial deficiencies in terms of flows and logistics, the territory has been marked by a re-concentration in the already privileged spaces of the territory.

Corporate planning, therefore, can be identified by its character of regional re-concentration in the Brazilian socio-spatial formation. The concessions promote a process of successive arrangements for the realization of capitalist accumulation in new spaces, forming a territory of spoliation in areas where the location promotes more profitability for airport activities. We can thus classify the Brazilian territory as a space of coexistence of renewed forms of spoliation through the process of concessions. The results show that there was a vertiginous increase in the flow of passengers between 1972 and 2010. It should be noted that this flow was accompanied by a combination of airports and networks of connections, consolidating a dispersed national network, although concentrated in the south / southeast region. Observing the topological pattern of the network, the hypothesis can be sustained that the airport network is today one of the main lines of interconnection of high value-added goods and transportation of top executives between the polarizing cities of the urban network (CORRÊA, 1977) justifying its importance for territorial planning.

In the developmental period, the productive and territorial integration of the country was organized by state investments in circulation infrastructures that could articulate the network of cities, in order to meet the functional integration of the urban centers in the sense of dynamizing an internal market anchored in new objects designated for the integration of the national territory. Its subsequent concession process also revealed a new pattern of territorial articulation and insertion in the international economy, since, as Vainer (2007) points out, the state withdrew from the infrastructure sectors that helped to consolidate it in the developmental period, thus also giving territorial planning to the extraverted interests of large corporations.

Therefore, the major initial investment in planning was made through state-owned infrastructure companies. With the spoliation of these systems the planning came to be done by the agents of capital. These are large organizations that redefine the actions in the territories through corporate management models, spread worldwide by companies linked to the global order of the spoliative accumulation process. A corporate use of territory gained the form of corporate planning. As a result, they deepen the asymmetric and concentrated pattern of Brazilian socio-spatial formation, revealing that, ultimately, corporate planning deepens the inequalities of the regional and territorial division of labor, driving the continuity of the planning of poverty (SANTOS, 2007). 


\section{BIBLIOGRAPHIC REFERENCE}

ABEAR. Panorama 2015: o setor aéreo em dados e análises. 2015

ANAC. Relatório de desempenho regulatório. Rio de Janeiro, 2008.

ANAC. Estudo econômico sobre regulação e concorrência no setor de aeroportos. Rio de Janeiro, 2009.

ANAC. Editais: Concessão: Aeroportos de Guarulhos, Viracopos e Brasília. Disponível em http://www2. anac.gov.br/gru-vcp-bsb, 2011.

ANTAS JR, Ricardo M. Território e regulação. São Paulo: Associação Editorial Humanitas: Fapesp, 2005. ANTUNES, Ricardo. Os sentidos do Trabalho. São Paulo: Boitempo, 1999.

BENKO, Georges. Economia, Espaço e Globalização na Aurora do Século XXI. São Paulo: Hucitec, 1996. BRANDÃO, Antônio Carlos. Território e Desenvolvimento. Campinas: Editora da Unicamp, 2007.

CANO, Wilson. Concentração e desconcentração econômica e regional no Brasil: 1970/95. Revista Economia e Sociedade, Campinas, (8), p. 101-141, jun. 1997.

CORREAA, Roberto Lobato. O sistema urbano brasileiro. Revista brasileira de geografia. Rio de janeiro, número 39 (3), p 92-111, Jul/Set. 1977.

CORRÊA, Roberto Lobato. Rede urbana e formação espacial. Revista Território, Rio de Janeiro, ano V, n.8, p. 121-129, Jan/Jun., 2000.

HARVEY, David. O novo imperialismo. São Paulo: Loyola, 2004.

HARVEY, David. Os limites do capital. São Paulo: Boitempo, [1982] 2013.

HARVEY, David. Condição Pós-Moderna. 25 ed. São Paulo: Loyola, [1989] 2014.

FERNANDES, Florestan. A revolução burguesa no Brasil. São Paulo: Ed. Globo, $5^{\mathrm{a}}$ ed, 2006.

FURTADO, Caio. Formação Econômica do Brasil, São Paulo: Ed. Nacional, 18ª ed., [1959]1982.

IBGE - Instituto Brasileiro de Geografia e Estatística. Região de Influência de Cidades 2007. Rio de Janeiro, 2008.

IBGE - Instituto Brasileiro de Geografia e Estatística. Redes e fluxos do território: ligações aéreas 2010. Rio de Janeiro, 2010.

IBGE - Instituto Brasileiro de Geografia e Estatística. Redes e fluxos do território: Centros de Gestão no Território. Rio de Janeiro: 2014.

LÊNIN, Vladimir I. A formação do Capitalismo na Rússia. São Paulo: Abril Cultura, 1982.

PRADO Jr., Caio. A Revolução Brasileira. São Paulo: Ed. Brasiliense, 2ª ed., 1966.

MATTELART, Armand. Comunicação Mundo. Petrópolis: Rio de Janeiro: Editora vozes, 1994.

MCKINSEY\&COMPANY. Estudo do setor de transporte aéreo do Brasil. Rio de Janeiro, 2010.

MORAES, Antônio, C. R. Notas sobre formação territorial e políticas ambientais no Brasil. Texto apresentado durante o Congresso Brasil - Portugal: Lisboa, 2000.

OLIVEIRA, Francisco. Elegia para uma re(li)gião. 5. ed. Rio de Janeiro: Paz e Terra, 1987.

PRADO JUNIOR, Caio. Formação do Brasil Contemporâneo: colônia. 12. ed. São Paulo: Brasiliense, 1972.

SANTOS, Milton. Sociedade e espaço: a formação social como teoria e método. Boletim paulista de geografia, $\mathrm{n}^{\mathrm{o}}$ 54, p. 81-101, 1977.

SANTOS, Milton. Metrópole corporativa e fragmentada. São Paulo: Nobel, 1990.

SANTOS, Milton. A Natureza do Espaço. 3a ed. São Paulo: Hucitec, 1999.

SANTOS, Milton. Por uma outra globalização. Rio de Janeiro: Editora Record, 2011.

SANTOS, Milton. Da totalidade ao lugar. São Paulo: Edusp, 2005.

SANTOS, Milton. Economia Espacial: Críticas e alternativas. São Paulo: Edusp, 2007.

SANTOS, Milton. Metamorfoses do espaço habitado. São Paulo: Edusp, 2008.

SANTOS, Milton; SILVEIRA, Maria Laura. O Brasil. Rio de Janeiro: Record, 2001. 
VAINER, Carlos B. Fragmentação e Projeto Nacional. XII Encontro da Associação Nacional de Pós-Graduação e Pesquisa em Planejamento Urbano e Regional. Belém, 2007. 